\title{
Effectiveness of Digital-Based Agricultural Extension Implementation in Central Bangka Regency
}

\author{
Ahmadi, Akhmad Ansyor ${ }^{*}$, Suharyanto and Zikril Hidayat \\ BPTP Kepulauan Bangka Belitung, Indonesian Agency for Agricultural Research and Development, \\ Pangkalpinang, 33134, Indonesia
}

\begin{abstract}
This study aims to determine the effectiveness of the implementation of digital-based counseling in Central Bangka Regency. Respondents in this study were 335 people consisting of farmers and agricultural extension officers in 6 (six) districts in Central Bangka Regency. Data were collected through survey activities using a questionnaire. The data obtained were analyzed based on quantitative analysis using the Logit test. Based on the research results, it was found that all the variables studied were significantly related to the effectiveness of digital-based extension implementation in the Central Bangka Regency.
\end{abstract}

\section{Introduction}

Agricultural development is an integrated, holistic, systematic, and sustainable activity. One of the elements of agricultural development is the presence of advanced and dynamic technology that can be adopted. This technology will have a positive impact if it has been utilized by users, both direct users such as farmers and entrepreneurs and indirect users such as policy makers. The problem of agricultural development is the low level of adoption and application of agricultural technology in the farming system carried out by farmers.

The Ministry of Agriculture, through the Agricultural Research and Development Agency, in recent years has produced a package of agricultural technology innovation, both from food crops, horticultural crops, plantation commodities, and livestock. However, the problem so far is that technology innovation has not been adopted by farmers or is slow, the cause is (1) lack of communication on information dissemination, socialization, publication and dissemination of these technological innovations, both among agricultural extension officers or between agricultural extension officers and farmers, (2) The lack of ability of farmers in utilizing digital media as a reference in obtaining information technology, and (3) Limited resources of agricultural extension officers in implementing extension using digital media.

This study aims to increase the acceleration (acceleration), hardening and effectiveness of the Ministry of Agriculture's research results through digital media. Weak and slow

*Corresponding author: ancuiycool@gmail.com 
delivery of information communication and the adoption of location-specific technology to users hampers the dissemination of innovation / technology from the results of locationspecific research and development to the community. Efforts to increase the acceleration of technology adoption must be made by further enhancing communication, coordination and acceleration of technological innovation with related parties. This increase in adoption can be done with a dissemination approach that is more adapted to the current millennial era, namely through the dissemination of technological innovations through digital media.

The output of this study is expected to accelerate the process of spreading technological innovation to farmers. The faster the user farmers get the information they need, the faster they will solve the problems they face. In addition, the speed with which technological innovation is accepted, it can improve the cognitive abilities of user farmers towards agricultural innovation.

Straubhaar, et al [1] explains that rural communities, especially farmers, also really need to increase their agricultural business capacity. The agricultural business needed by farmers is found in the entire cultivation process they do, harvest, and harvest. Furthermore, farmers also really need skills in the marketing process of their agricultural products. Agricultural management, entrepreneurial activities, networks, and other capabilities are in accordance with the demands of the times. The needs of farmers in the current millennial era can be met quickly through mastery of information technology. There are various media that function to provide opportunities for people to find their needs. The need can be felt urgent if someone has been faced with a problem. In addition, needs can also be felt important if someone has the desire to increase their cognitive level [1].

According to Susilowati [2] several applications that can be used by the Agricultural Extension Officer include: Cyber Extension: A media innovation or counseling platform developed by Agricultural Human Resources Development Agency (BPSDMP) containing material and information to facilitate the implementation of extension. This application can be found by opening the site cybex.pertanian.go.id.

1. Katam (Integrated Planting Calendar): In this integrated Katam application, agricultural instructors can take advantage of the correct planting time information according to climatic conditions, in Katam can be obtained information on season predictions and rainfall predictions, information on planting time and potential planting area. This application can be accessed via a computer by accessing the site http://katam.litbang.pertania.go.id, or via cellphone by accessing the android version of the Katam can be downloaded via Playstore.

2. MyAgri (Android-Based Vegetable Cultivation Information System): Vegetable Research Institute (BALITSA) has designed this application and users can download it on Playstore.

3. Takesi (Android Technology for Cow Health): Takesi is a cow health application developed by the Center for Veterinary Research Agency (BBLIVET). The application contains information about reproductive diseases and disorders in brood stock, diseases and disorders in calves, cow health management and expert contacts. This application can be owned by downloading via the Playstore.

4. Coffee Experts: this application Developed by BALITRI, contains questions and answers about coffee problems, in which information is obtained about coffee cultivation, coffee consuls and pest consuls. Applications can be downloaded on the Playstore

5. Sapa Mektan is an android based application which can be downloaded via Playstore. Sapa Mektan is an application published by the Center for Agricultural Mechanization (BB Mektan) of the Ministry of Agriculture. 
Based on the results of Mulyandari [3], it was found that by utilizing information technology, farmers felt the benefits of improving communication, access to information and means of promotion. In line with the results of this study, with socialization activities and training on the use of information technology, farmers have succeeded in increasing the level of accessibility of technology-based information systems for empowering farmers in making agricultural business decisions [4].

Prayoga [5] found that the information dissemination process could be obtained evenly by user farmers using various agricultural applications. In addition, with the use of various agricultural applications, it can attract young people to farm, and farmers can more easily sell their agricultural products. Rendra et al. [6] found the results of research that there was a strong relationship between increasing the human resources of agricultural extension officer, Head of Farmer and Farmer Groups and the use of digital-based extension application media in the aspects of knowledge and skills in using digital media.

From the results of his research, Permana [7] found that the performance of agricultural extension officer was influenced by internal and external factors. Internal factors that can influence are the competence of an agricultural extension officer. External factors that can influence include the availability of facilities by the Institution / Government and leadership. Furthermore, in terms of the performance of agricultural extension officer. Utami [8] obtained the results of research that there is a real relationship between extension facilities equipment and media accessibility with communication behavior and the relationship between agricultural extension officer's communication behaviors.

\section{Method}

This study was conducted in July - December 2019 at 6 (six) BPPs in Central Bangka Regency. It is hoped that the data obtained will determine the level of use of digital media by agricultural extension agents in the process of implementing agricultural extension in the Central Bangka Regency.

This study was conducted with a participatory approach using the Purposive Selection method, with farmers and agricultural extension officers as respondents. The scope of digital media is digital media commonly used in Indonesia, namely social media and available agricultural applications. The social media that will be studied include Facebook, Twitter, Instagram and Youtube. Agricultural applications that will be studied include Cyber Extension, SI KATAM, MyAgri, TAKESI, Coffee Expert, and Sapa Mektan. This study will also carry out Technical Guidance regarding the use of digital media for user farmers and the use of media for agricultural extension officers. The purpose of holding this technical guidance is to determine the level of adoption of user farmers in receiving digital-based information. In addition, this technical guidance is also carried out to determine the level of ability of agricultural extension officers in carrying out extension by using digital media.

This study was conducted with a focus on activities, namely the use of digital media in the process of implementing agricultural extension officers. The use of digital media can be in the form of social media or agricultural applications that are already available. The process of implementing extension can be seen from the level of farmer adoption and the types of methods and media used by agricultural extension officers in the agricultural extension implementation.

This study uses primary data and secondary data. Primary data collection was carried out using survey techniques using a questionnaire. Primary data will be analyzed quantitatively. Secondary data were obtained from various institutions and literature related to this study. 
Quantitative analysis in this study uses the Logit test to determine the factors that influence the digital-based agricultural extension process in Indonesia, the Logit test is used with the equation:

$$
Y i=\alpha+\beta 1 X 1+\beta 2 X 2+\beta 3 X 3+\beta 4 X 4+\beta 5 X 5+\beta 6 X 6+\beta 7 X 7+\beta 8 X 8+\beta 9 X 9
$$

Information:

If $\mathrm{Y}=1$ farmer and / or agricultural extension officer has information technology capability If $\mathrm{Y}=0$ farmers and / or agricultural extension officer do not have information technology skills

$\mathrm{X} 1=$ Variable of Age

$\mathrm{X} 2=$ Variable of Educational

X3 = Variable of Understanding Using Digital Media

X4 $=$ Variable of Intensity of Digital Media Usage

X5 = Variable of Intensity of Extension Activity

X6 = Variable Number of Digital Equipment Owned

X7 $=$ Variable Number of Digital Media Owned

$\mathrm{X} 8=$ Variable of Experience

$\mathrm{X} 9=$ Variable of Expenditure

$\alpha=$ constanta

$\beta 1-\beta n=$ Regression coefficient

\section{Results and Discussion}

This study was conducted on 335 (three hundred and thirty five) respondents from 6 (six) Districts in Central Bangka Regency. Respondents consisted of 65 agricultural extension officers and 270 farmers

Table 1. Relationships among variables to the effectiveness of digital-based extension implementation with a logistic regression model.

\begin{tabular}{|c|c|c|c|c|c|c|c|c|c|}
\hline \multicolumn{10}{|c|}{ Variables in the Equation } \\
\hline & & \multirow{2}{*}{ B } & \multirow{2}{*}{ S.E } & \multirow{2}{*}{ Wald } & \multirow{2}{*}{$\begin{array}{l}\mathrm{d} \\
\mathrm{f}\end{array}$} & \multirow{2}{*}{ Sig. } & \multirow{2}{*}{$\operatorname{Exp}(B)$} & \multicolumn{2}{|c|}{ 95\% C.I.for $\operatorname{Exp}(B)$} \\
\hline & & & & & & & & Lower & Upper \\
\hline $\begin{array}{l}\text { Step } \\
1\end{array}$ & Age & .654 & .739 & 2.368 & 1 & .014 & 1.852 & .882 & 3.890 \\
\hline & Educational & 6.631 & 2.977 & 5.962 & 1 & .107 & 758.542 & 3.268 & 176.130 .865 \\
\hline & $\begin{array}{l}\text { Understanding } \\
\text { Using Digital Media }\end{array}$ & 1.933 & .470 & 3.720 & 1 & .701 & 3.815 & .895 & 14.280 \\
\hline & $\begin{array}{l}\text { Intensity of Digital } \\
\text { Media Usage }\end{array}$ & 4.736 & 2.333 & 3.159 & 1 & .601 & 79.554 & .823 & 7.699 .975 \\
\hline & $\begin{array}{l}\text { Intensity of } \\
\text { Extension Activity }\end{array}$ & -1.203 & .088 & 1.064 & 1 & .025 & .360 & .075 & 1.750 \\
\hline & $\begin{array}{l}\text { Number of Digital } \\
\text { Equipment Owned }\end{array}$ & -8.743 & 3.291 & 4.760 & 1 & .032 & .000 & .000 & .460 \\
\hline & $\begin{array}{l}\text { Number of Digital } \\
\text { Media Owned }\end{array}$ & -7.474 & 4.464 & 2.870 & 1 & .094 & .000 & .000 & 3.889 \\
\hline & Experience & -2.611 & 2.248 & .670 & 1 & .384 & .121 & 002 & 14.050 \\
\hline & Expenditure & 2.960 & 3.382 & .943 & 1 & .484 & 14.731 & .008 & 26.918 .960 \\
\hline
\end{tabular}

Based on the results of the assessment, it was found that the variables tested in this study consisted of 9 (nine) independent variables. The logit test results show that there is a relationship between independent variables on the implementation process of digital-based 
agricultural extension in Indonesia. This can clearly be seen in table 1.

Based on table 1, it is known that Number of Digital Equipment Owned and Number of Digital Media Owned have an Exp (B) value below the lower limit (95\% C.I. for Exp (B)). This means that number of digital equipment owned, and number of digital media owned have a very significant influence on the extension implementation of digital-based in Indonesia with a $99 \%$ of confidence level. Meanwhile, Age, Education, Understanding of Using Digital Media, Intensity of Using Digital Media, Intensity of Extension Activities, Experience and Expenditures have a significant influence on the extension implementation of digital-based in Indonesia with a 95\% of confidence level. This can be explained by the value of the Exp (B) variable between the Lower - Upper interval of $95 \%$ C.I. for $\operatorname{Exp}(\mathrm{B})$.

Age is one of the respondent's internal variables which is thought to be related to the extension implementation of digital-based. From the results of the interview, it was revealed that the age of the respondents varied from the youngest 21 years to the oldest 63 years. Judging from that age range, overall respondents are in productive age. That is, the opportunity to carry out digital-based extension is large [9]. In addition, Mita, et al. [10] explained that age can influence a person in making decisions about an object.

Apart from age, the education level of the respondents is also an internal factor that can influence the digital-based agricultural extension implementation. The education level of the respondents varies with the vulnerable from primary school to tertiary education. Respondents who have a low level of education are respondents who received formal education to high school. While the higher education level is the respondent who received postgraduate formal education. The level of education greatly influences someone in doing what they want [11]. [12] added that the level of education can have a positive or negative influence on a person's decision to do something.

Based on table 1, it is known that Age, Number of Digital Equipment Owned and Number of Digital Media Owned have an Exp (B) value below the lower limit (95\% C.I. for $\operatorname{Exp}(\mathrm{B})$ ). This means that age, number of digital equipment owned, and number of digital media owned have a very significant influence on the extension implementation of digital-based in Indonesia with a $99 \%$ of confidence level. Meanwhile, Education, Understanding of Using Digital Media, Intensity of Using Digital Media, Intensity of Extension Activities, Experience and Expenditures have a significant influence on the extension implementation of digital-based in Indonesia with a $95 \%$ of confidence level. This can be explained by the value of the Exp (B) variable between the Lower - Upper interval of $95 \%$ C.I. for $\operatorname{Exp}(\mathrm{B})$.

Understanding of using digital media correlates with the number of digital media owned by respondents. The more respondents understand certain digital media, the more often they will even use that digital media. Based on the results of this study, it was found that not all respondents understood the application that was the test indicator, so not all respondents had various amounts of digital media in using this digital media. This is because the applications used by respondents tend to go to other social media. [13] Kamila, et al. [13] found that the higher the respondent's understanding of an optical object, the more diverse the object will be used.

The number of digital equipment owned by the respondent is related to the intensity of the respondent's use of digital media. The more digital equipment the respondent has, the higher it will be in using the application. According to [14], the relationship between the amounts of goods produced in a production activity (output) with the production factors used (input). Aminah, et al. [15] obtained research results that the number of equipment owned by respondents in conducting an audit using an application (system) is significantly related to the high intensity of respondents using the application (system) in auditing. Furthermore, [16] found that there is a very real relationship between the intensity of using 
digital equipment in manufacturing work and the number of digital equipment owned by the company.

Respondents experiences relate to the amount of expenditure of respondents in implementing digital-based counseling. The more experienced the respondent is, the higher the cumulative expenditure he has made. Sanusi, et al. [17] explained that innovation adoption is influenced by the experience of the community or group in the surrounding environment. The more experienced people around them, the faster and more precise the adoption process will be. The driving factor for a person to gain extensive experience is expenditure. The higher a person's expenditure in an effort to obtain something, the higher the experience in undergoing the achievement process [18].

Table 2. The results of the analysis of the influence of variables on the effectiveness of digital-based extension implementation in Central Bangka.

\begin{tabular}{|l|l|r|r|rr|}
\hline \multicolumn{7}{|c|}{ Omnibus Test of Model Coefficients } \\
\hline & & Chi-square & df & Sig. & .001 \\
\hline $\begin{array}{l}\text { Step } \\
1\end{array}$ & Step & 32.484 & 8 & & .001 \\
\hline & Block & 32.484 & 8 & & .001 \\
\hline & Model & 32.484 & 8 & Nagelkerke R \\
\hline \multicolumn{7}{|c|}{ Model Summary } \\
\hline Step & -2 Log & Cox \& Snell R & & Square \\
\hline \multicolumn{7}{|c|}{ Likelihood } & Square & & .872 \\
\hline 1 & $19117^{\text {a }}$ & .683 & & & \\
\hline
\end{tabular}

Table 2 explains that the significant value of the omnibus test is below 0.05 with a confidence level of $95 \%$. The Omnibus Test with 9 (nine) independent variables resulted in a significance value lower than 0.05 . This shows that there is a significant influence of the nine independent variables simultaneously affecting the implementation of digitalbased extension in Indonesia. Then the Nagelkerke R Square value is the R squared value in linear regression. This means that each of the nine variables is able to influence $87 \%$ of the implementation of digital-based extension in Indonesia, while the other $13 \%$ of the implementation of digital-based extension in Indonesia can be explained by other factors outside of these nine variables.

The authors would like to gratitude to Dr. Ir. Arivin Rivaie, M.Sc for his support and input in the implementation of this research until finished. Furthermore, the authors thank you to Prof. Rubiyo for his assistance on this research.

\section{Conclusion}

The digital-based on agricultural extension implementation is effective to do for farmers in the Central Bangka Regency. The applications can be found on Google Play Store.

\section{References}

1. Straubhaar, Joseph, Rober LaRose. Wadswroth, (2002)

2. S. S. Abidin, Kebijakan Publik (Salemba Humanika, Jakarta, 2012)

3. Susilowati. Sinartani, (2019)

4. Mulyandari, R. S. H., IPB University, (2011)

5. Sumardjo., Journal of Ilmu-ilmu Pertanian, 61 (2010) 
6. Prayoga, K., Galuh University, (2015)

7. Rendra, Jamaluddin, Fendria Sativa., LPMP Jambi University, 3 (2019)

8. Permana, R, Polbangtan YOMA, 16 (2019)

9. Utami, D. A., IPB University, (2019)

10. Rawung, J.B.M, Indrasti, R, Hutapea, R.T.P., Journal of Penelitan Pertanian Tanaman Pangan. 3 (2019)

11. Mita, Y. T, Haryono, D, Marlina, L., Lampung University, 6 (2018)

12. Nurwahyuni, A, Syamola, D., University of Indonesia, (2017)

13. Wicaksono, K. P, Soeleman, M, A, Pramunendar, R, A., Dian Muswantoro University, 14 (2018)

14. Kamila, W, C., Samsudin, A., University of Pendidikan Indonesia, (2019)

15. Sudarman, A., Algifari., BPFE, (2001)

16. Aminah, Wirdhaningtyas, A., Uniersity of Bandar Lampung, 8 (2017)

17. Wahyuningrum, S., Universty of Negeri Semarang, (2016)

18. Sanusi, I., Mahfudz, M., Siswadi, B., University of Islam Malang, (2018)

19. Kurniawan, B., Dewi, N., Yulida, R., Journal of Ilmu Ekonomi Pertanian Indonesia, 8 (2017) 